\title{
Innovative development of human capital in the conditions of globalization
}

\author{
Oleh Kuzmin ${ }^{1}$, Myroslava Bublyk ${ }^{1, *}$, Alyona Shakhno ${ }^{2}$, Olha Korolenko ${ }^{2}$, and Hanna Lashkun ${ }^{2}$ \\ ${ }^{1}$ Lviv Polytechnic National University, Lviv, 79013, Ukraine \\ ${ }^{2}$ Kryvyi Rih National University, Kryvyi Rih, 50027, Ukraine
}

\begin{abstract}
The role of human capital in the innovative development of the Ukrainian economy, which is formed through investment in the human being, is investigated. It is determined that an indispensable condition for sustainable development of the country is the implementation of the strategy of increasing the quality of human capital, which is actively involved in innovation processes and serves as a key resource for improving the competitiveness of the national economy. Emphasis is placed introduction of the model "lifelong learning" using modern technologies. A methodological approach to determining the level of innovative development of human capital is proposed and the value of the integral index of innovative development of human capital is calculated. The innovative-investment model of human capital development in the conditions of globalization is developed and the directions are defined. To overcome the problems of inefficient development of human capital and to improve its quality, a set of measures will be proposed that will contribute to the innovative development of the economy. The scientific novelty is to deepen theoretical provisions and to develop scientific and practical recommendations for improving the quality of human capital and its innovative development in the context of accelerating globalization processes.
\end{abstract}

\section{Introduction}

The integration of Ukraine into the international economic space, where globalization is accelerating and competition between countries is increasing, has led to the need to form an innovative model of the economy. An indispensable condition for sustainable development, ensuring a high-tech competitive environment is the innovative development of the country, which is a paramount strategy in post-industrial society. The realization of a certain strategy is possible only if the quality of human capital is increased, where the creative potential of the person, mental abilities, knowledge, professionalism comes to the fore. As a person with his intellect creates and implements innovations, takes an active part in innovation processes, the development and improvement of the quality of human capital is a prerequisite for building an innovation and investment model of an economy in the conditions of sustainable development, which made the current research relevant.

Of particular importance is the development of the educational component of personality. The introduction of the "life-long learning" model and the efficient use of highly skilled labor resources will in the future increase the competitive advantages of the national economy.

The purpose of the article is to identify the main tools for innovative human development as a key factor in increasing the competitiveness of the national economy, to build an innovation-investment model of human capital development and to identify priority areas for improving its quality in a globalized environment.

The realization that a person is at the center of all economic processes and acts as a major factor in the innovative development of the economy, the requirements for the quality of human capital are increasing. Today in Ukraine there is a transition to the information society, which is characterized by the growing role of intellectual activity of man, his ability to innovate. The result of such activities is the creation of high-tech products, which is key to shaping the country's GDP. Therefore, the formation of innovative human capital and the definition of its development prospects in modern conditions require further scientific research.

The theory of human capital has been gradually developed in accordance with the stages of development of world economic theory and conditions of social production, which focuses on the intellectual, creative and productive qualities of man as the main factor of economic growth. The concept of human capital was introduced into science in the 1960th. The founders of the human capital theory are G. Becker [1-2] and T. Schultz [3-4].

T. Schultz [3] first used the term "human capital". He noted that education is a form of capital. In his view, human capital is a set of knowledge, abilities, motivations that are the source of future income and enjoyment. T. Schultz [4] argued that investing in a person is an investment in education, health care, and

\footnotetext{
* Corresponding author: my.bublyk@gmail.com
} 
science. T. Schultz [4] believed that the educational level of a person influences the ability to use new technologies, information that will provide competitive advantages of economic development. For the first time, T. Schultz proved that human capital is capable of accumulation and reproduction. T. Schultz [4] considered human capital at the macro level, that is, at the level of the country's economy.

G. Becker [1-2] investigated this category at the micro level, i.e. at the enterprise level. G. Becker [1] created a theoretical basic model of human capital as a set of knowledge, skills, skills and expanded the definition of this category. G. Becker [2] Proposed for human capital assessment to take into account investments not only in education, science, health care, but also the costs of training and retraining in manufacturing, computer training, physical and spiritual development, as well as indirect costs in the form of lost income during the period of study.

Many scholars have explored the theory and methodology of human development, but there is no consensus on human capital development. A significant contribution to the theoretical and methodological development of problems of human capital development was made by famous foreign scientists $H$. Bowen [5], L. Thurow [6], F. Machlup [7], J. Mincer [8] and others.

Considerable attention was paid to the issues of formation, use and innovative development of human capital by domestic scientists. O. Amosha, A. Degtyar [9] formed a methodological aspect of human capital in the conditions of an innovative economy. V. Antoniuk [10] studied socio-economic assessment and development assurance of the formation and use of human capital in Ukraine. M. Bublyk, O. Rybytska [11] examined the pollution impact on the mortality rate in Ukraine. Methodological bases of human, intellectual and social capital development assessment are presented by O. Grishnova [12]. E. Libanova [13] investigated the influence of social and demographic factors of human development and modernization of the national economy, A. Turilo [14] proposed the concept of human capital assessment and management. The impact of human capital on the innovation capacity of companies is investigated by L. Lavrinenko [15]. R. M. MarizPérez, M. M. Teijeiro-Alvarez, M. T. García-Alvarez [16] investigated the relevance of human capital as a driver for innovation.

H. McGuirka, H. Lenihanb, M. Hartc [17] measured the impact of innovative human capital on small firms' propensity to innovate. C. Diebolt and R. Hippe [18] established the long-run impact of human capital on innovation and economic development in the regions of Europe. Ł. Bryl [19] conducted a comparative analysis of US corporations in the human capital orientation and financial performance. T. H. Aas and K. J. Breunig [20] built a contingency perspective of conceptualizing innovation capabilities. T. Kraśnicka, W. Głód and M. Wronka-Pośpiech [21] explained the nature of management innovation and proposed five-dimension management innovation model: strategic dimension, structural dimension, employee motivation and development dimension.

\section{Innovative development of human capital as a basis for sustainable economic development}

In the context of globalization transformations, the modern paradigm of innovative development of human capital is a key lever of increasing the competitiveness of the country, a major factor in the development of an innovative and investment model of state development [22]. With the development of scientific and technological progress, information and communication technologies, human capital occupies a central place as a carrier of intelligence, knowledge, skills, experience, and professionalism.

Human development is a continuous process of qualitative and quantitative changes that lead to an increase in the level of education, culture of man, his mental and spiritual maturity. Innovative development of human capital is characterized by fundamentally new approaches that are embodied in the introduction of a new model of "life-long learning" and the formation of a new model of working life, where the main focus is innovative work; the application of social technologies, innovative forms of employment, the use of new models of working time, etc. Increasing investment in human development (from the state, business, personality) leads to an increase in its level of intellectualization, which is the basis for sustainable economic development.

Foreign experience [23] shows that the formation of an innovative model of economic development requires the introduction of a regulatory policy of the state aimed at the development of institutions that will provide a favorable microclimate for the innovative development of human capital, enhancing its competitiveness.

Global studies on the level of innovative development of countries have been conducted since 2007 as part of a joint project of INSEAD International Business School, Cornell University and the World Intellectual Property Organization (WIPO) [24-26]. The Global Innovation Index is defined as a set of indicators that characterize the level of innovative development of countries in the world at different levels of economic development. The calculation methodology includes 80 parameters, grouped in two directions (index calculation is defined as a weighted sum of estimates of two groups of indicators - from 0 to 100): 1. Available resources and conditions for innovation (Innovation Input): Institutes; human capital and research; development of the internal market; infrastructure; business development. 2. Outcomes of Innovation Output: Development of Knowledge and Technology Economy; results of creative activity implementation.

The ranking of the world countries according to the Global Innovation Index, which allows evaluating the effectiveness of efforts to introduce and develop innovations in a country, is presented in Table 1 [24-26].

Table 1 data shows that over the 2017-2019 period among other countries of the world that participated in the Innovation Survey, Ukraine improved its position from 50 places to 47 , although it lost four positions compared to 2018 (where it was 43 place). The Global 
Innovation Index in 2019 was 37.40, but it is the least significant compared to previous years. This indicates a lack of use of resources and the innovative potential of the country. The leaders of the world in the Global Innovation Index are the developed countries: Switzerland, Sweden, the Netherlands, the United States of America, the index of which exceeds 60 points. Ukraine's economy is much inferior to other developed countries in terms of innovative development.

Table 1. Global Innovation Index Rankings 2017-2019.

\begin{tabular}{|c|c|c|c|c|c|c|}
\hline \multirow{2}{*}{ Country } & \multicolumn{2}{|c|}{$\mathbf{2 0 1 7}$} & \multicolumn{2}{c|}{$\mathbf{2 0 1 8}$} & \multicolumn{2}{|c|}{$\mathbf{2 0 1 9}$} \\
\cline { 2 - 7 } & Rank & $\begin{array}{c}\text { Innova- } \\
\text { tion In- } \\
\text { dex }\end{array}$ & Rank & $\begin{array}{c}\text { Innova- } \\
\text { tion In- } \\
\text { dex }\end{array}$ & Rank & $\begin{array}{c}\text { Innova- } \\
\text { tion In- } \\
\text { dex }\end{array}$ \\
\hline Switzerland & 1 & 67,69 & 1 & 68,40 & 1 & 67,24 \\
\hline Sweden & 2 & 63,83 & 3 & 63,08 & 2 & 63,65 \\
\hline Netherlands & 3 & 63,36 & 2 & 63,32 & 4 & 61,44 \\
\hline $\begin{array}{c}\text { United States } \\
\text { of America }\end{array}$ & 4 & 61,40 & 6 & 59,81 & 3 & 61,73 \\
\hline $\begin{array}{c}\text { United } \\
\text { Kingdom }\end{array}$ & 5 & 60,89 & 4 & 60,13 & 5 & 61,30 \\
\hline Germany & 9 & 58,39 & 9 & 58,03 & 9 & 58,19 \\
\hline Ireland & 10 & 58,13 & 10 & 57,19 & 12 & 56,10 \\
\hline Japan & 14 & 54,72 & 13 & 54,95 & 15 & 54,68 \\
\hline Canada & 18 & 53,65 & 18 & 52,98 & 17 & 53,88 \\
\hline Norway & 19 & 53,14 & 19 & 52,63 & 19 & 51,87 \\
\hline China & 22 & 52,54 & 17 & 53,06 & 14 & 54,82 \\
\hline Belgium & 27 & 49,85 & 25 & 50,50 & 22 & 50,18 \\
\hline Poland & 38 & 41,99 & 39 & 41,67 & 39 & 41,31 \\
\hline Turkey & 43 & 38,90 & 50 & 37,42 & 49 & 36,95 \\
\hline $\begin{array}{c}\text { Russian } \\
\text { Federation }\end{array}$ & 45 & 38,76 & 46 & 37,90 & 46 & 37,62 \\
\hline Ukraine & $\mathbf{5 0}$ & $\mathbf{3 7 , 6 2}$ & $\mathbf{4 3}$ & $\mathbf{3 8 , 5 2}$ & $\mathbf{4 7}$ & $\mathbf{3 7 , 4 0}$ \\
\hline Armenia & 59 & 35,65 & 68 & 32,81 & 64 & 33,98 \\
\hline Georgia & 68 & 34,39 & 59 & 35,05 & 48 & 36,98 \\
\hline Belarus & 88 & 29,98 & 86 & 29,35 & 72 & 32,07 \\
\hline Tajikistan & 94 & 28,16 & 101 & 26,51 & 100 & 26,43 \\
\hline Yemen & 127 & 15,64 & 126 & 15,04 & 129 & 14,49 \\
\hline
\end{tabular}

The implementation of innovation policy depends on the effectiveness of the state regulatory policy, based on which regulatory acts are adopted, namely the Laws of Ukraine "On Innovative Activity", "On Priority Areas of Innovative Activity in Ukraine", "On the National Program of Informatization", "On Higher Education", "On Education", "On the National Strategy for the Development of Education in Ukraine until 2021", Strategy for development and utilization of labor potential in Ukraine for the period up to 2025, etc.

\section{Tools for innovative development of human capital}

The main tools for innovative development of human capital are [27-28]: 1. Legal instruments (laws, regulations, strategies, and programs in the direction of innovative development of human capital). 2. Financial instruments. Government expenditures for: health care; education and vocational training; spiritual and physical development of human capital; social protection of the population, etc. 3 . Tools for raising the educational and professional level of human capital. The country has a national educational policy, the tools of which are: educational programs, licenses, accreditations, dual education, educational innovative technologies. Modern tools of human resources are E-learning - distance learning, corporate university (business education), online lectures and more. There are innovative forms and types of employment (outsourcing, outstaffing, outplacement, staff leasing, coworking, personnel audit, HR consulting, etc.). 4. Infrastructure development tools (venture and innovation funds, technoparks and science parks, start-ups, online information resources, patented government agencies, innovation promotion marketing centers, etc.). 5. Instruments of social influence (social technologies and projects: "adaptation technology of young specialists", "technology of conflict resolution", "technology of recruitment", "technology of certification of specialists", technologies of search of management strategy, technologies of social modeling and forecasting, information technologies, Employee Social Card, gamification (search for custom solutions, etc.).

\section{A methodological approach to determining the level of innovative development of human capital}

In many works, both foreign and domestic scientists have laid the methodological foundations for assessing the development of human capital. The study of theoretical and methodological approaches to assessing the development of human capital has made it possible to determine that the most common method is the integral evaluation of the indicator.

Analyzing methodological approaches [29] to assessing the development of human capital necessitated the development of its methodology, which would allow taking into account modern requirements for human capital in the conditions of the innovative economy taking into account the tendencies of globalization.

We propose our methodological approach to determining the integral index of innovative development of human capital, which has the following algorithm:

Step 1. Determination of analytical indicators that influence the innovative development of human capital, bringing them to a single measure.

Step 2. Selection of factors of influence and verification of their values on multicollinearity using the economic-mathematical method of constructing a matrix of paired correlation coefficients (correlation matrix), which has the following form (formula 1):

$$
k^{*}=\left|\begin{array}{cccccc}
k_{y y} & k_{y x_{1}} & k_{y x_{2}} & k_{y x_{3}} & \ldots & k_{y x_{m}} \\
k_{x_{1} y} & k_{x_{1} x_{1}} & k_{x_{1} x_{2}} & k_{x_{1} x_{3}} & \ldots & k_{x_{1} x_{m}} \\
k_{x_{2} y} & k_{x_{2} x_{1}} & k_{x_{2} x_{2}} & k_{x_{2} x_{3}} & \ldots & k_{x_{2} x_{m}} \\
\ldots & \ldots & \ldots & \ldots & \ldots & \ldots \\
k_{x_{m} y} & k_{x_{m} x_{1}} & k_{x_{m} x_{2}} & k_{x_{m} x_{3}} & \ldots & k_{x_{m} x_{m}}
\end{array}\right|
$$

Even correlation coefficients estimate the relationship between pairs of variables: independent $x_{i}$ and dependent $y\left(k_{x_{i} y}\right)$, independent $x_{j}$ and dependent $y$ 
$\left(k_{x_{j} y}\right)$, independent variables $x_{i}$ and $x_{j}\left(k_{x_{i} x_{j}}\right)$. The correlation matrix of pairwise regression coefficients is symmetric $k\left(k_{x_{i}} k_{x_{j}}\right)$ (formula 2$)$ :

$$
k_{x x}=X^{* \prime} X^{*}
$$

The elements of this matrix show the close relationship of one variable with another.

Step 3. Normalization of values of indicators that will ensure their comparability $\left(Z_{i j}\right)$. They are broken down into stimulus and stimulus metrics:

1) For indicators-stimulants (formula 3):

$$
Z_{i j}=\frac{X_{i j}-X_{j \min }}{X_{j \max }-X_{j \min }}
$$

where $X_{i j}$ - the value of the $j$-th indicator in the $i$-th period; $X_{j \min }$ - the minimum value of the $j$-th indicator in the $i$-th period; $X_{j \max }-$ the maximum value of the $j$-th indicator in the $i$-th period.

The stimulus value ranges from 0 to 1 , where 0 is the worst value, 1 is the best value. Its growth contributes to an increase in the index of the innovative development of human capital.

2) For indicators-stimulators (their growth decreases the index of human development) (formula 4):

$$
Z_{i j}=\frac{X_{j \max }-X_{i j}}{X_{j \max }-X_{j \min }}
$$

The determined stimulus is between 0 and 1 , where 0 is the worst value, 1 is the best value.

Step 4. Calculation of the weight value of each indicator using the economic-mathematical method of determining the correlation coefficients (formula 5):

$$
\sum_{j=1}^{n} v_{j}=1
$$

Step 5. Determination of partial indices of innovative development of human capital (formula 6):

$$
I_{i j}=\sum_{j=1}^{n} Z_{i j} v_{j}
$$

where $Z_{i j}-$ a normalized $j$-th indicator of human development in the $i$-th period; $v_{j}$ - the weight with which the $j$-th index is calculated when determining the integral index; $n$-number of indicators.

Step 6. Determination of the integral index of innovative development of human capital $P_{\text {innov }}$ (formula 7):

$$
P_{\text {innov }}=\sum_{j=1}^{n} I_{i j}
$$

The calculation of the integral index of the innovative development of human capital is presented in Table 2. The integral indicator of the innovative development of human capital is graphically presented in Fig. 1.

As can be seen from the data in Table 1 and Fig. 1, the integral index of the innovative development of human capital for the analyzed period decreases, which is a negative trend. In the country, there is a decrease: the number of employees involved in the implementation of research and development; the number of graduates of higher education institutions and the number of graduate and doctoral students. The declining trend of the innovative development of human capital leads to a deterioration of the quality of human capital, which negatively affects the GDP of the country, reducing the competitive advantages of the national economy.

Table 2. Estimated values of the integral index of the innovative development of human capital.

\begin{tabular}{|c|c|c|c|c|c|c|}
\hline & $\begin{array}{c}\text { Number of } \\
\text { employees } \\
\text { involved } \\
\text { in the im- } \\
\text { plementa- } \\
\text { tion of re- } \\
\text { search and } \\
\text { develop- } \\
\text { ment, } \\
\text { Issued } \\
\text { thousands } \\
\text { lists } \\
\text { from } \\
\text { the } \\
\text { HEA, } \\
\text { thou- } \\
\text { sand } \\
\text { people }\end{array}$ & $\begin{array}{c}\text { Num- } \\
\text { ber of } \\
\text { gradu- } \\
\text { ate stu- } \\
\text { dents, } \\
\text { thou- } \\
\text { sand } \\
\text { people }\end{array}$ & $\begin{array}{c}\text { Num- } \\
\text { ber of } \\
\text { docto- } \\
\text { ral stu- } \\
\text { dents, } \\
\text { thou- } \\
\text { sand } \\
\text { people } \\
\text { of inno- } \\
\text { vators } \\
\text { in the } \\
\text { total } \\
\text { number } \\
\text { of in- } \\
\text { dustrial } \\
\text { enter- } \\
\text { pri- } \\
\text { ses, }\end{array}$ & $\begin{array}{c}\text { In- } \\
\text { indica- } \\
\text { tor of } \\
\text { inno- } \\
\text { vative } \\
\text { deve- } \\
\text { lop- } \\
\text { ment of } \\
\text { human } \\
\text { capital }\end{array}$ \\
\hline 2010 & 182,484 & 543,7 & 34,653 & 1,561 & 11,5 & 0,792 \\
\hline 2011 & 175,33 & 529,8 & 34,192 & 1,631 & 12,8 & 0,798 \\
\hline 2012 & 164,34 & 520,7 & 33,64 & 1,814 & 13,6 & 0,782 \\
\hline 2013 & 155,386 & 485,1 & 31,482 & 1,831 & 13,6 & 0,670 \\
\hline 2014 & 136,123 & 405,4 & 27,622 & 1,759 & 12,1 & 0,377 \\
\hline 2015 & 122,504 & 374,0 & 28,487 & 1,821 & 15,2 & 0,440 \\
\hline 2016 & 97,912 & 318,7 & 25,963 & 1,792 & 16,6 & 0,306 \\
\hline 2017 & 94,274 & 359,9 & 24,786 & 1,646 & 14,3 & 0,233 \\
\hline 2018 & 88,128 & 357,4 & 22,829 & 1,145 & 15,6 & 0,211 \\
\hline
\end{tabular}

\section{Correlation-regression model of innovative development of human capital}

To establish the relationship between the factors influencing the innovative development of human capital, a multivariate least-squares regression model was constructed using a methodological model proposed by scientists [29] for constructing models. The results of the calculations are given in Table 3.

Table 3. An econometric model of innovative development of human capital.

\begin{tabular}{|c|c|c|c|}
\hline $\begin{array}{c}\text { Indicator } \\
\text { (dependent } \\
\text { variable Y) }\end{array}$ & Model & $\begin{array}{c}\text { Adequacy } \\
\text { of Fisher's } \\
\text { models }\end{array}$ & $\begin{array}{c}\text { Student's } \\
\text { t-test }\end{array}$ \\
\hline GDP & $\begin{array}{c}\mathrm{Y}=-1,0121+0,0203^{*} \mathrm{X} 1+ \\
0,0196^{*} \mathrm{X} 24+4,0425^{*} 10^{\wedge}- \\
06^{*} \mathrm{X} 3, \mathrm{R}^{2}=0,928\end{array}$ & $\begin{array}{c}17,0936 \\
(0,0096)\end{array}$ & $\begin{array}{c}\mathrm{F} \\
(2,850>\mathrm{t}\end{array}$ \\
& \multicolumn{2}{|c|}{$\left.{ }^{2}, 776\right)$} \\
\hline
\end{tabular}

Table 2 data show that a considerable number of factors, both direct and indirect, influence on the development of human capital are taken into account in economic and mathematical models. The factors selected were the most significant in its development. The constructed multivariate regression models show that the correlation between the factors exists and is sufficiently stable. The multiple determination coefficient indicates how much the resultant index depends on the factor traits. 
All models were tested for adequacy using the Fisher and Student t-test, which are compared with the table values.

The coefficients of the equation show the quantitative influence of each factor (with the invariance of the others) on the resultant index. The greater the modulus of the value of the coefficient of the independent variable, the greater the impact it has on the resultant index.

Analyzing the model of the influence of factors of development of human capital on the growth of GDP of the country made it possible to determine that the resultant GDP is the greatest influence of such factor as the expected duration of studies. The least impact of the factor is population migration. The increase in the level of education of human capital of Ukraine, the use of modern information and communication technologies and the implementation of the model "life-long learning" will positively influence the growth of social productivity, which will contribute to the growth of GDP of the country.

Innovation-investment model of human capital development in the conditions of globalization is presented in figure 2 .



Fig. 1. Integral indicator of innovative development of human capital.

\section{Areas of improving the quality of human capital}

The formation of quality human capital is the main vector of the development of an innovative economy in the conditions of globalization. In our opinion, to overcome the problems of inefficient development of human capital and improve its quality, the state must take a set of measures that will contribute to the innovative development of the economy, namely:

- improving the legal framework towards ensuring the conditions for the effective reproduction and development of human capital;

- improvement of the state innovation policy and effective use of instruments of innovative development of human capital taking into account foreign experience; - creation of appropriate institutional environment and adoption of programs for innovative development of human potential;

- creation of an effective mechanism for professional training of highly qualified specialists and raising their level of qualification taking into account the requirements of the modern labor market;

- formation of a new model of working life, based on the development of innovative forms and types of employment;

- enhancing the role of social dialogue and social partnership;

- improvement of the state migration policy to minimize the loss of human capital outflow;

- introduction of information and communication and social technologies, which will increase the level of development of human capital in post-industrial society;

From our point of view, the implementation of the proposed measures will help to increase the quality of human capital, which is a key resource for the development of an innovative economy and increase the competitiveness of the state.

\section{Conclusion and perspectives}

Thus, the innovative development of human capital is a 
major factor in building a model of sustainable economic development in the context of globalization transformations, as it is formed through investment in human beings. The effectiveness of investment is determined by the level of development of productive abilities of the individual, capable of innovative work, creativity, creativity. The growth of the role of human capital in the conditions of sustainable development of the innovative economy necessitates the use of new approaches to its assessment, formation, and development. An important role in the reproduction of human capital is played by the state, which pursues regulatory policy using regulatory acts. The formation of an effective organizational and economic mechanism of state regulation of human capital development is a priority task that will create appropriate conditions for increasing the quality of human capital, its innovative potential, which will enhance the competitiveness of the national economy.

Further research will be to develop strategic directions and mechanisms for the development of innovative human capital, using the foreign experience of developed countries.

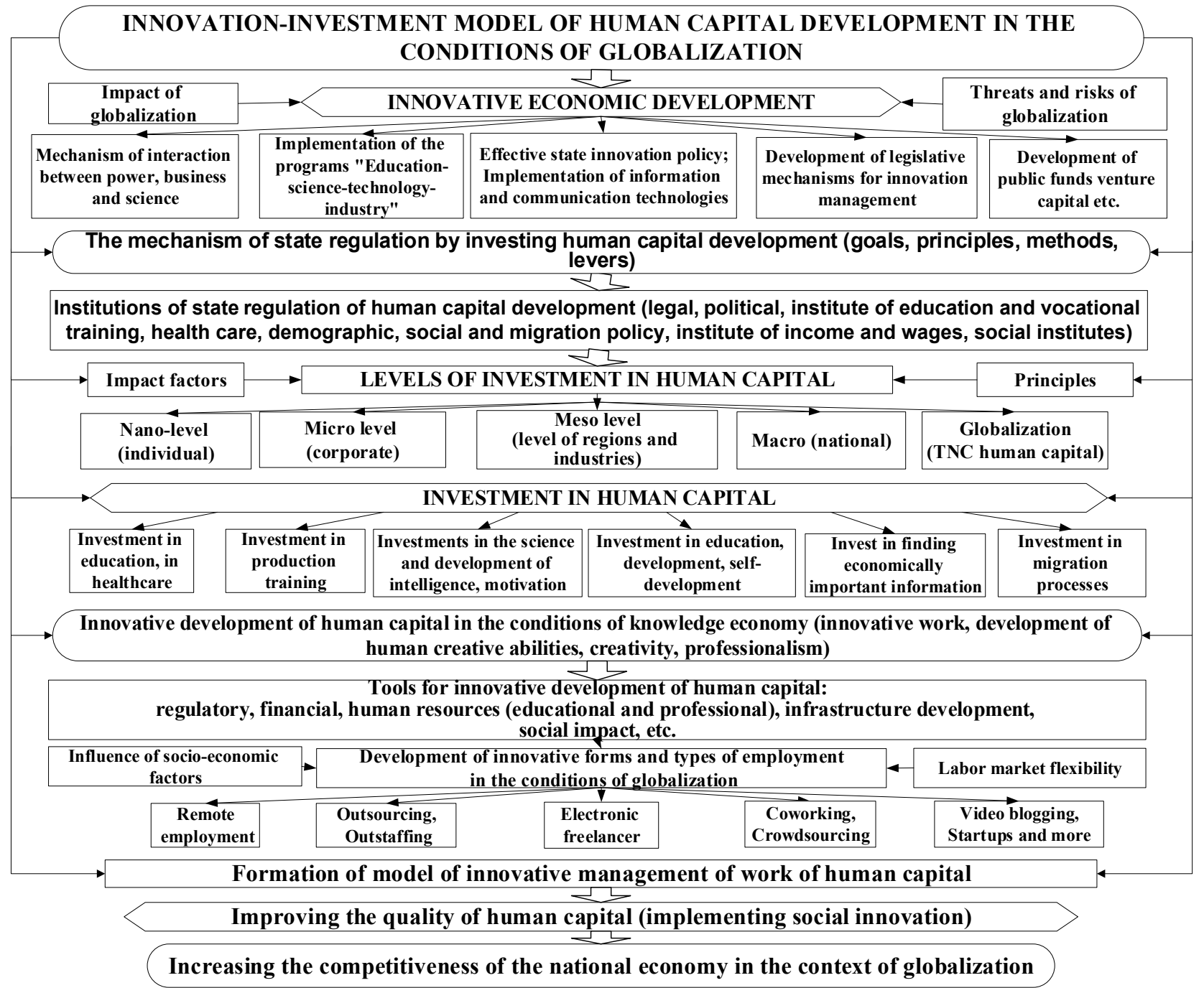

Fig. 2. Innovation and investment model of human capital development in the conditions of globalization.

\section{References}

1. G.S. Becker, Human Capital: a Theoretical and Empirical Analysis, with Special Reference to Education (National Bureau of Economic Research, New York, 1964)

2. G.S. Becker, Human Capital (The University of Chicago Press, Chicago, 1993)

3. T. Shultz, Human Capital: Policy Issues and Research Opportunities (National Bureau of Economic Research, New York, 1972)
4. T. Schulz, Educ. Econ. 1, 10 (1993)

5. H.R. Bowen, Investment in Human Capital and Economic Growth: Perspectives on Economic Growth (Bantam Books, New York, 1968)

6. L. Thurow, C. Lester, Investment in Human Capital (Belmont, Wadsworth Publishing Company, 1970)

7. F. Machlup, Knowledge: Its Creation, Distribution, and Economic Significance. The Economics of Informations and Human Capital, vol. 3 (Princeton University Press, Princeton, 1984)

8. J. Mincer, Work. Pap of NBER, 4838 (1994) 
9. O. Amosov, A. Degtyar, Derzhava i rynok 3, 164 (2011)

10. V.P. Antonyuk, Formuvannia ta vykorystannia liudskoho kapitalu $v$ Ukraini: sotsialnoekonomichna otsinka ta zabezpechennia rozvytku (Formation and use of human capital in Ukraine: socio-economic assessment and development assurance). (Institute of Industrial Economics, Donetsk, 2007)

11. M. Bublyk, O. Rybytska, in Proceedings of the 12th International Scientific and Technical Conference on Computer Sciences and Information Technologies, 2017, vol. 1, pp. 253-256. doi:10.1109/STC-CSIT.2017.8098781

12. O.A. Grishnova, Sotsialno-trudovi vidnosyny: teoriia ta praktyka 1, 34 (2014)

13. E.M. Libanova (ed.), Liudskyi rozvytok v Ukraini: sotsialni ta demohrafichni chynnyky modernizatsii natsionalnoi ekonomiky (Human development in Ukraine: social and demographic factors of modernization of the national economy). (Ptoukha Institute for Demography and Social Studies of the NAS of Ukraine, Kyiv, 2012)

14. A.M. Turylo, Ekonomichnyi chasopys 2(18), 44 (2019)

15. L.M. Lavrinenko, Stalyi rozvytok ekonomiky 1(23), 18 (2014)

16. R.M. Mariz-Péreza, M.M. Teijeiro-Alvarez, M.T. García-Alvarez, Cuad. de Eco. 35(98), 68 (2012)

17. H. McGuirka, H. Lenihanb, M. Hartc, Res. Pol. 44, 965 (2015)

18. C. Diebolt, R. Hippe, The long-run impact of human capital on innovation and economic development in the regions of Europe. Appl. Econ. 51(5), 542-563 (2019). doi:10.1080/00036846.2018.1495820

19. Ł. Bryl, J. Entr. Man. Innov. 14(3), 61 (2018)

20. T.H. Aas, K.J. Breunig, J. Entr. Man. Innov. 13(1), 7 (2017)

21. T. Kraśnicka, W. Głód, M. Wronka-Pośpiech, J. Entr. Man. Innov. 12(2), 95 (2016)

22. O.S. Kvasha, Naukovyi visnyk Uzhhorodskoho natsionalnoho universytetu 6(1), 150 (2016)

23. A.A. Sánchez, G.S. Marín, A.M. Morales, Eur. J. Man. Bus. Econ. 24(3), 138 (2015)

24. S. Dutta, B. Lanvin, S. Wunsch-Vincent (eds.), Global Innovation Index 2017: Innovation Feeding the World (Cornell University, INSEAD, WIPO, 2017), https://www.wipo.int/edocs/pubdocs/en/wipo_pub_g ii 2017.pdf. Accessed 22 Dec 2019

25. S. Dutta, B. Lanvin, S. Wunsch-Vincent (eds.), Global Innovation Index 2018: Energizing the World with Innovation (Cornell University, INSEAD, WIPO, 2018), https://www.wipo.int/publications/en/details.jsp?id= 4330. Accessed 22 Dec 2019
26. C. Jewell, GII 2019: Creating Healthy Lives - the Future of Medical Innovation (2019), https://www.wipo.int/wipo magazine/en/2019/04/ar ticle_0001.html. Accessed 22 Dec 2019

27. O.A. Iermakova, Mekhanizm rehuliuvannia ekonomiky 1, 85 (2016)

28. M. Bublyk, V. Koval, O. Redkva, Market. Manag. Innov. 4, 229-240 (2017). doi:10.21272/mmi.2017.4-20

29. O. Kuzmin, M. Bublyk, in Proceedings of the XIth International Scientific and Technical Conference on Computer Sciences and Information Technologies (2016), pp. 37-39. doi:10.1109/STCCSIT.2016.7589863

30. State Statistics Service of Ukraine (Kyiv, 2020), http://www.ukrstat.gov.ua. Accessed 02 Jan 2020 